ENHANCED COAL BED METHANE PRODUCTION AND SEQUESTRATION OF $\mathrm{CO}_{2}$ IN UNMINEABLE COAL SEAMS

Semi-Annual Technical Progress Report

April 1, 2004 through September 30, 2004

William A. Williams

October 2004

DOE Cooperative Agreement DE-FC26-01NT41148

\title{
CONSOL ENERGY.
}

CONSOL Energy Inc.

Research \& Development

4000 Brownsville Road

South Park, PA 15129 


\section{DISCLAIMER}

This report was prepared as an account of work sponsored by an agency of the United States Government. Neither the United States Government nor any agency thereof, nor any of their employees, makes any warranty, express or implied, or assumes any legal liability or responsibility for the accuracy, completeness, or usefulness of any information, apparatus, product, or process disclosed, or represents that its use would not infringe privately owned rights. Reference herein to any specific commercial product, process, or service by trade name, trademark, manufacturer, or otherwise does not necessarily constitute or imply its endorsement, recommendation, or favoring by the United States Government or any agency thereof. The views and opinions of authors expressed herein do not necessarily state or reflect those of the United States Government or any agency thereof. 


\begin{abstract}
This is the sixth semi-annual Technical Progress report under the subject agreement. During this report period, progress was made on drilling the north, center, and south well sites. Water production commenced at the center and south well sites. New drilling plans were formulated for the last remaining well, which is in the Upper Freeport Seam at the north site. Core samples were submitted to laboratories for analytical testing. These aspects of the project are discussed in detail in this report.
\end{abstract}




\section{TABLE OF CONTENTS}

Abstract

\section{LIST OF FIGURES}

Figure 1

Figure 2

Figure 3

Figure 4

Figure 5

Figure 6

Figure 7

Figure 8

Figure 9

Figure 10

Figure 11
South Site Excavation Work - June 2, 2004 5

South Site Horizontal Drilling Activities - July 28, $2004 \ldots \ldots \ldots \ldots \ldots \ldots \ldots \ldots \ldots . . . . . \ldots$

South Site Horizontal Drilling Activities - August 11, 2004 6 South Site Pittsburgh Seam Pumping Station, Upper Freeport Seam Rods and Tubing, Dewatering Station - September 9, 2004 .................. 6

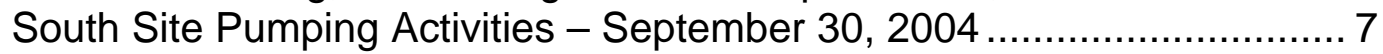

Center Site Excavating Activities - June 2, 2004 8

Center Site Drilling Activities - August 11, 2004 8 Center Site Upper Freeport Seam Drilling Activities with Vertical Well in Foreground and Access Well in Background - September 9, 2004 9 Center Site Upper Freeport Seam Southward Direction Venting System - September 30, 2004 9 Conceptual Perspective View of Project Wells..... 10 Revised Drill Plan - Freeport Seam North Well Site 11 


\section{INTRODUCTION}

The availability of clean, affordable energy is essential for the prosperity and security of the United States and the world in the $21^{\text {st }}$ century. Emissions of carbon dioxide $\left(\mathrm{CO}_{2}\right)$ into the atmosphere are an inherent part of electricity generation, transportation, and industrial processes that rely on fossil fuels. These energy-related activities are responsible for more than 80 percent of the U.S. greenhouse gas emissions, and most of these emissions are $\mathrm{CO}_{2}$. Over the last few decades, an increased concentration of $\mathrm{CO}_{2}$ in the earth's atmosphere has been observed. Carbon sequestration technology offers an approach to redirect $\mathrm{CO}_{2}$ emissions into sinks (e.g., geologic formations, oceans, soils and vegetation) and potentially stabilize future atmospheric $\mathrm{CO}_{2}$ levels. Coal seams are attractive $\mathrm{CO}_{2}$ sequestration sinks, due to their abundance and proximity to electricity-generation facilities. The recovery of marketable coalbed methane (CBM) provides a value-added stream, potentially reducing the cost to sequester $\mathrm{CO}_{2}$ gas. Much research is needed to evaluate this technology in terms of $\mathrm{CO}_{2}$ storage capacity, sequestration stability, commercial feasibility and overall economics.

CONSOL Energy Inc., Research \& Development (CONSOL), with support from the United States Department of Energy (USDOE) National Energy Technology Laboratory (NETL), has embarked on a seven-year program to construct and operate a coal bed sequestration site composed of a series of horizontally drilled wells that originate at the surface and extend through two overlying coal seams. Once completed, all of the wells will be used initially to drain CBM from both the upper (mineable) and lower (unmineable) coal seams. After sufficient depletion of the reservoir, centrally located wells in the lower coal seam will be converted from CBM drainage wells to $\mathrm{CO}_{2}$ injection ports. $\mathrm{CO}_{2}$ will be measured and injected into the lower unmineable coal seam while CBM continues to drain from both seams. In addition to metering all injected $\mathrm{CO}_{2}$ and recovered $\mathrm{CBM}$, the program includes additional monitoring wells to further examine horizontal and vertical migration of $\mathrm{CO}_{2}$.

This is the sixth Technical Progress report for the project. Progress this period was focused on drilling the north, center, and south well sites. Water production commenced at the center and south well sites. New drilling plans were formulated for the last remaining well, which is in the Upper Freeport Seam at the north site. Core samples were submitted to laboratories for analytical testing. This report provides a concise overview of project activities this period and plans for future work.

\section{EXECUTIVE SUMMARY}

During this period, progress was made on drilling the north, center, and south well sites. Water production commenced at the center and south well sites. New drilling plans were formulated for the last remaining well, which is in the Upper Freeport Seam at the north site. Core samples were submitted to laboratories for analytical testing. These aspects of the project are discussed in detail in this report. 


\section{EXPERIMENTAL}

The drilling plans are discussed, where appropriate, in the next section.

\section{RESULTS AND DISCUSSION}

\section{STATUS OF COOPERATIVE AGREEMENT}

Quarterly project status reports (DOE F 4600.6) were issued to DOE on August 6 and October 26, as required. In May, we participated in the International Coalbed Methane Symposium in Tuscaloosa, AL, and the Third Annual Carbon Capture \& Sequestration Conference in Alexandria, VA.

\section{PROGRESS - NORTH WELL SITE}

The three previously completed horizontal wells at the north well site consists of wells in the Pittsburgh Seam in the southeast direction, the Pittsburgh Seam in the southwest direction, and the Upper Freeport Seam in the southeast direction. Last year's efforts to dewater the north wells were hampered because communication between the sump and the horizontal component of the well (in the coal seam) was not fully established.

All three completed north site wells were reworked by attempting to removing the sump casing and re-entering the sump and horizontal element. The communication at the two Pittsburgh Seam wells was reestablished by this process. The Upper Freeport Seam well communication was not re-established, as the sump casing became entangled in the drill string and the horizontal element and sump junction collapsed. Therefore, the single existing Upper Freeport Seam north well was abandoned.

A new well, with horizontal legs, will be drilled in the Upper Freeport Seam based on the revised drilling method discussed in the Progress on Well Assessment section. A conceptual view of the project area is shown in Figure 10 including the north site wells.

\section{PROGRESS - SOUTH WELL SITE}

Well permits at the south well site were received. Drilling, including horizontal drilling in both the Pittsburgh Seam and Upper Freeport Seam, was completed at the south well site. The Pittsburgh Seam horizontal legs were completed at 2,850 feet and 3,000 feet in the northwest and northeast directions, respectively. The Upper Freeport Seam horizontal legs were completed at 2,500 feet and 1,500 feet in the northwest and northeast directions, respectively. The Upper Freeport horizontal legs were completed short of the target 3,000 feet due to thinning of the coal seam. Water pumping activities commenced in both the Pittsburgh and Upper Freeport seams. Figures 1 through 5 document the progress during this reporting period. A conceptual view of the project area is shown in Figure 10 including the south site wells. 


\section{PROGRESS - CENTRAL WELL SITE}

Site preparation work at this well site was completed. Well permits at the center well site were received and drilling was completed at the center well site. Each of the four Upper Freeport horizontal legs was completed at 1,000 feet. Water pumping activities completed in the Upper Freeport seam. Currently, the center site wells are venting gas. Figures 6 through 9 document the progress during this reporting period. A conceptual view of the project area is shown in Figure 10 including the center site wells.

\section{PROGRESS ON WELL ASSESSMENT}

The north well site communication problems were corrected for the two previously drilled Pittsburgh Seam horizontal legs.

The communication problem at the one previously drilled Upper Freeport Seam southeast horizontal leg could not be resolved, and the well was subsequently abandoned. The new Upper Freeport southeast horizontal leg and the Upper Freeport southwest horizontal leg will be drilled based on the design utilized at the south and center well sites. The design includes drilling a main production well and a second hole, which is drilled to produce the horizontal elements. This will allow for a perpendicular crossing of the production well and the horizontal element. These horizontal laterals will be drilled via production well "A" and horizontal element "B" as shown on Figure 10. The cross sectional view of the Upper Freeport Seam revised drill plan is shown in Figure 11.

\section{CORE SAMPLES}

Pittsburgh Seam and Lower Freeport Seam coal core samples were submitted to the USDOE NETL and Advanced Resources International for analytical testing and the results are pending.

\section{CONCLUSION}

The drilling activities were completed at the center site and south site. Water production commenced at the south site well. Gas is venting at the center site wells. The Pittsburgh Seam drilling at the north site was completed. The existing well in the Upper Freeport Seam at the north site was abandoned. New drilling plans were formulated for the last remaining well, which is in the Upper Freeport Seam at the north site. Core samples were submitted for analytical testing. 


\section{FORECAST}

During the next six months, gas gathering pipe will be installed from the north site to the south site and from the center site to the south site to gather the project coalbed methane at the south site. An amine plant will be installed at the south site to provide pipeline quality methane to the Columbia Gas Pipeline. Dewatering activities will continue at the south site wells and begin at the north site Pittsburgh seam wells.

\section{REFERENCES}

None 


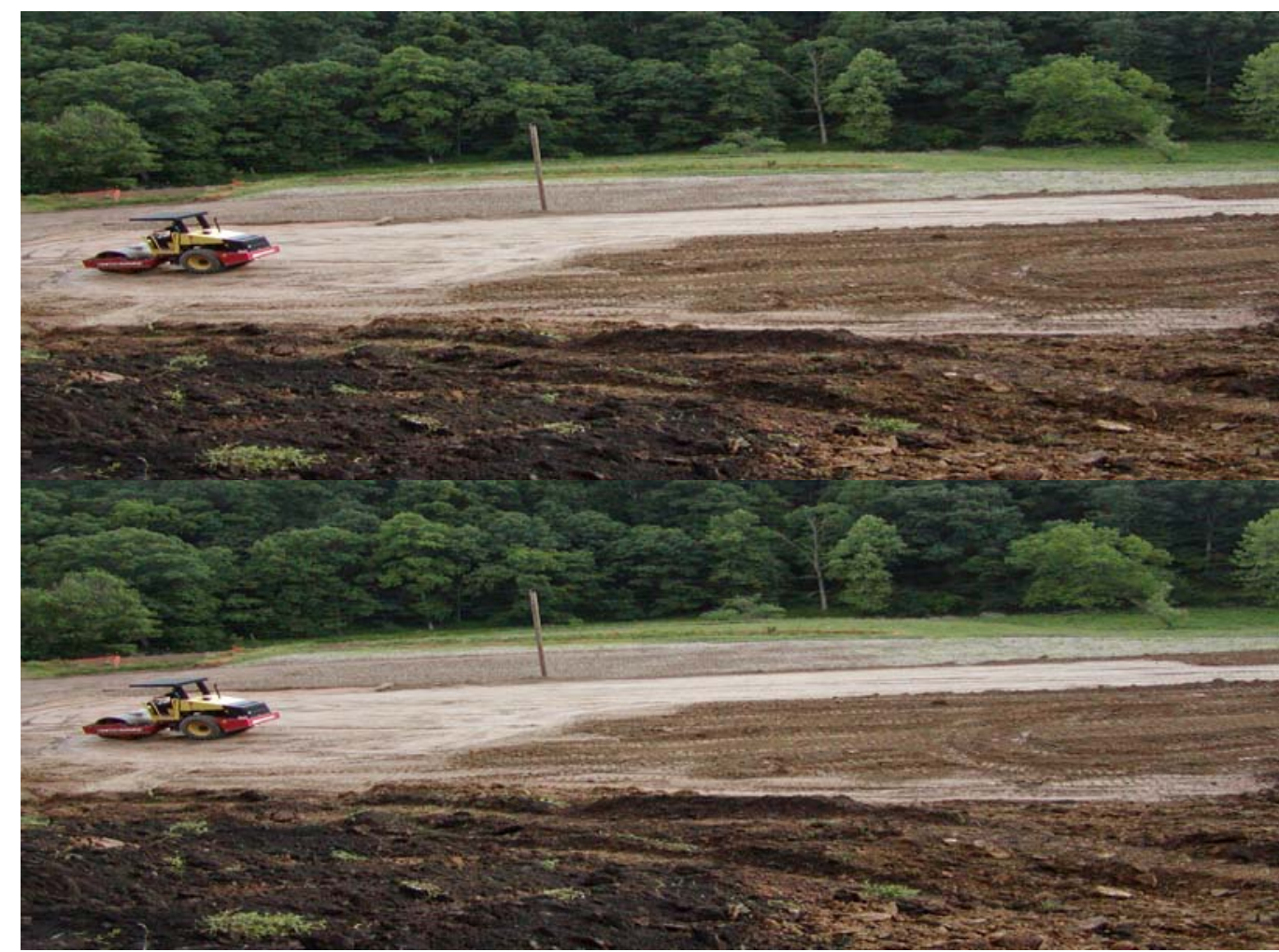

Figure 1: South Site Excavation Work - June 2, 2004
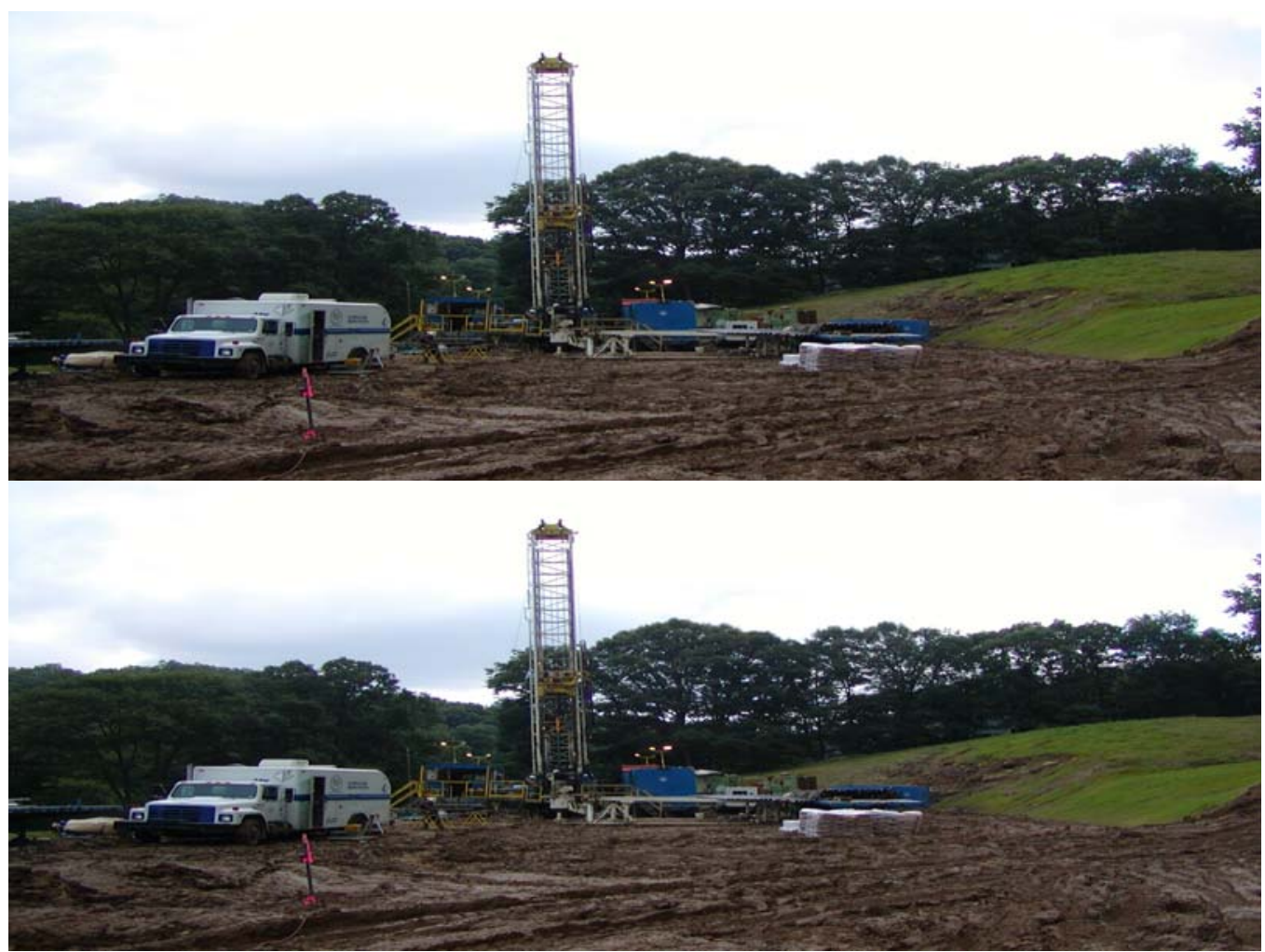

Figure 2: South Site Horizontal Drilling Activities - July 28, 2004 


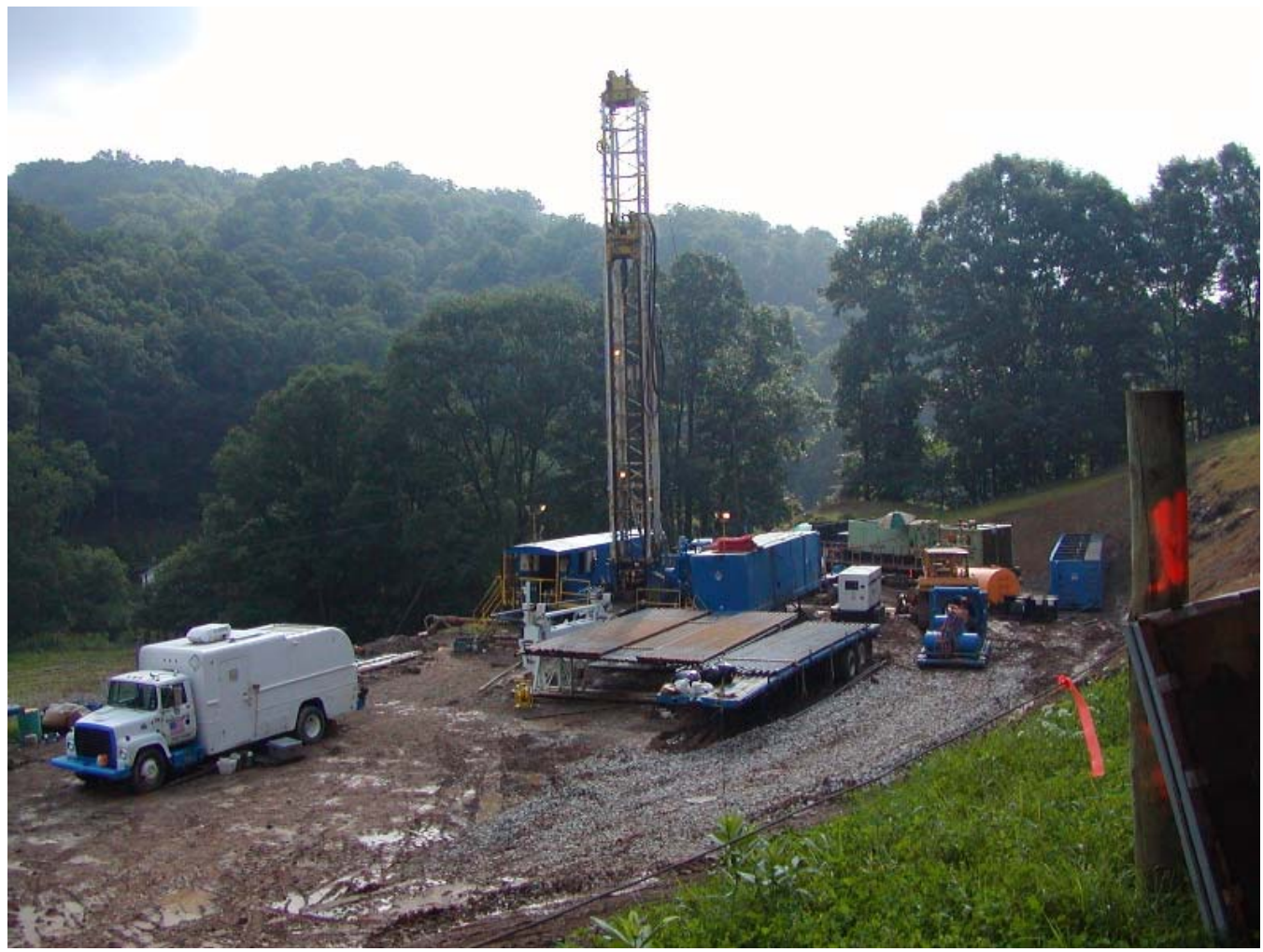

Figure 3: South Site Horizontal Drilling Activities - August 11, 2004

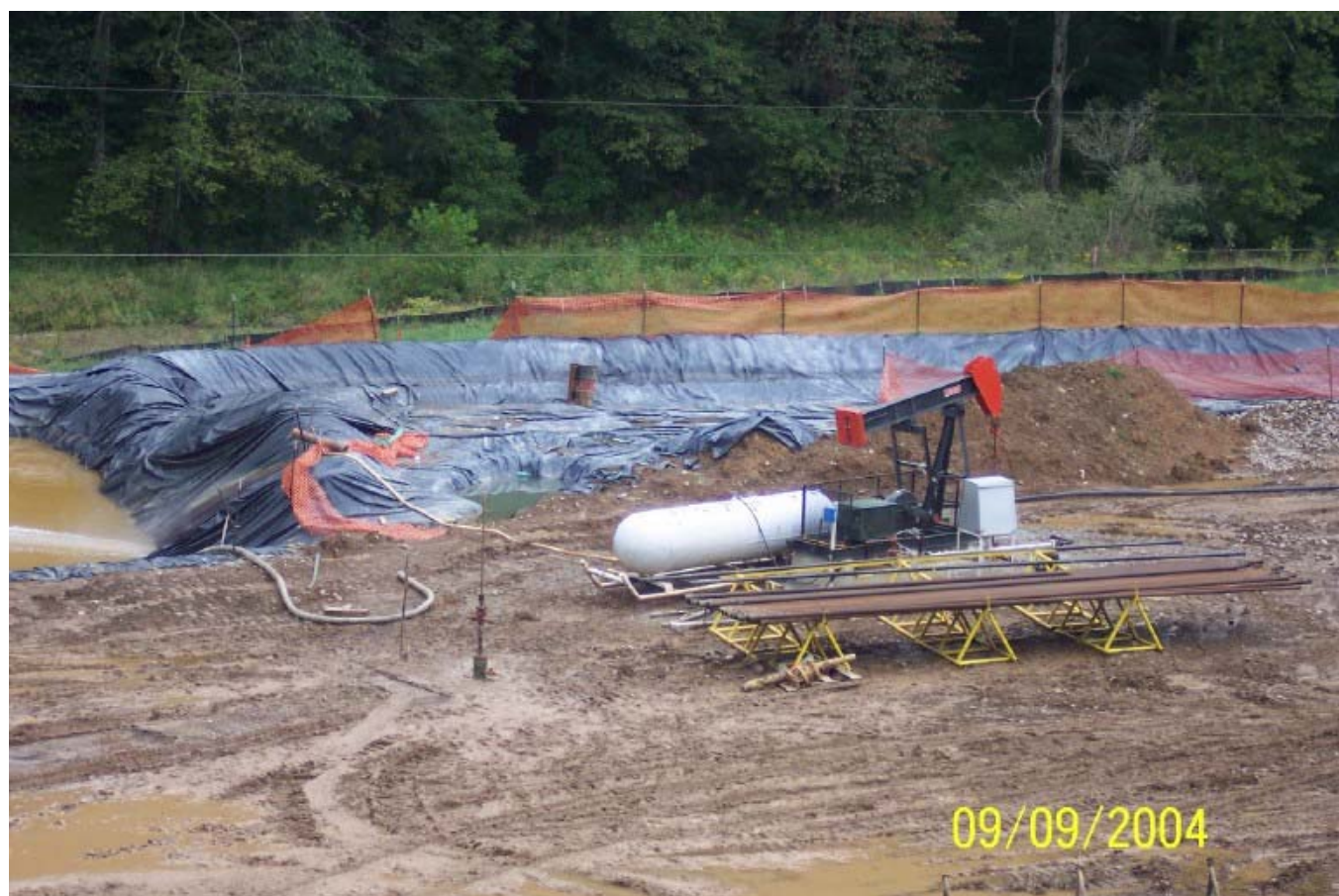

Figure 4: South Site Pittsburgh Seam Pumping Station, Upper Freeport Seam Rods and Tubing, Dewatering Station - September 9, 2004 


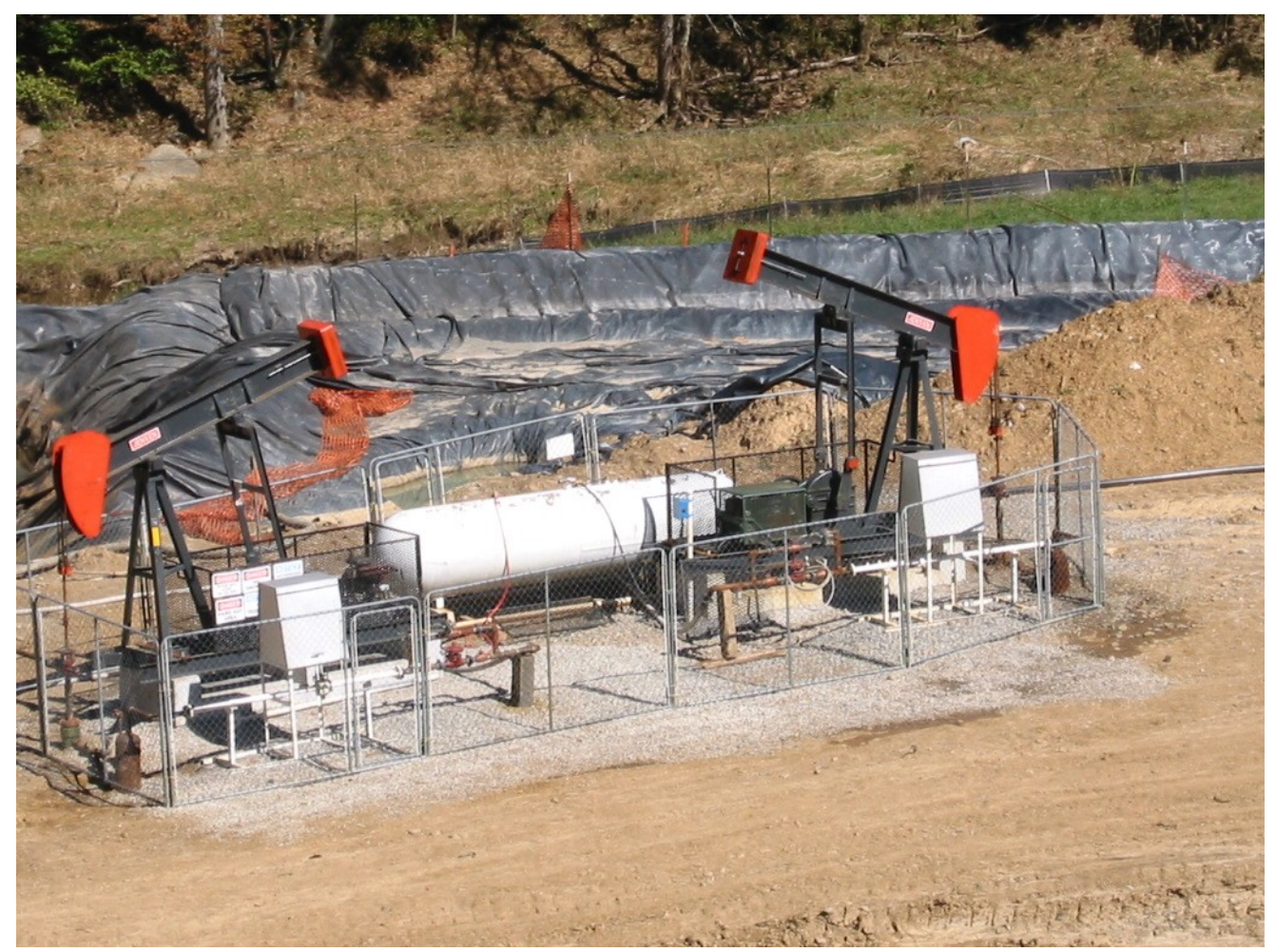

Figure 5: South Site Pumping Activities - September 30, 2004 


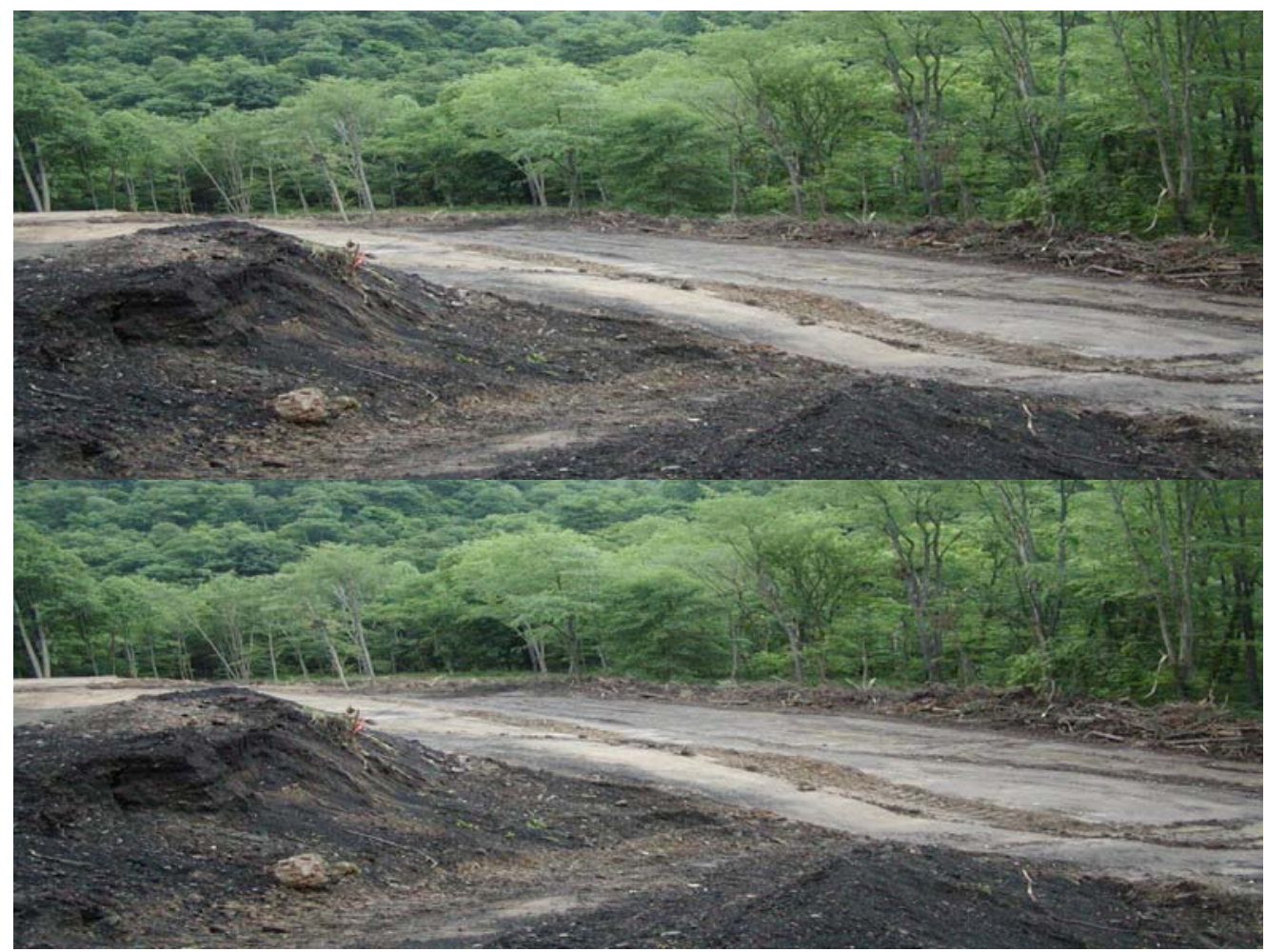

Figure 6: Center Site Excavating Activities - June 2, 2004

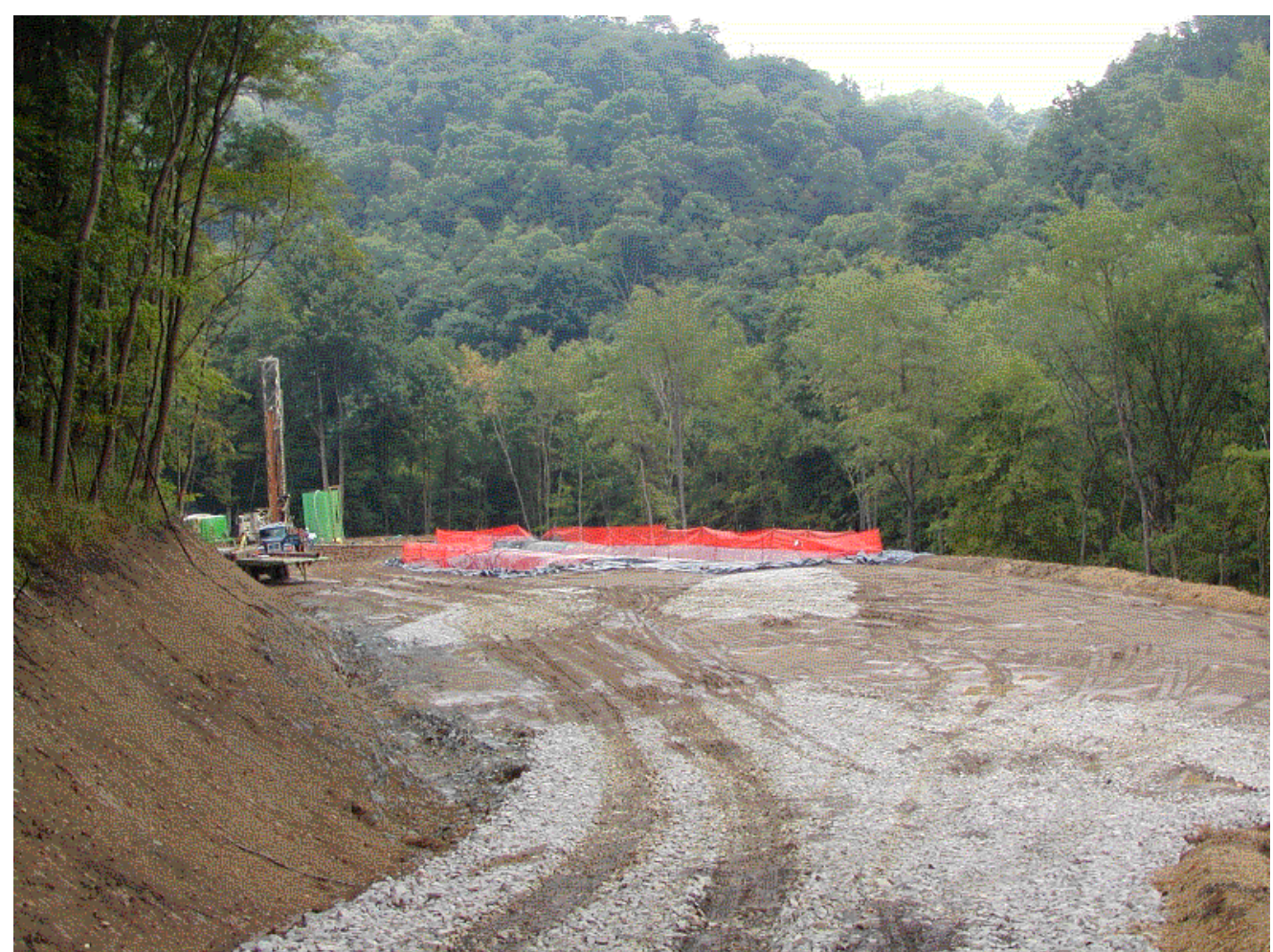

Figure 7: Center Site Drilling Activities - August 11, 2004 


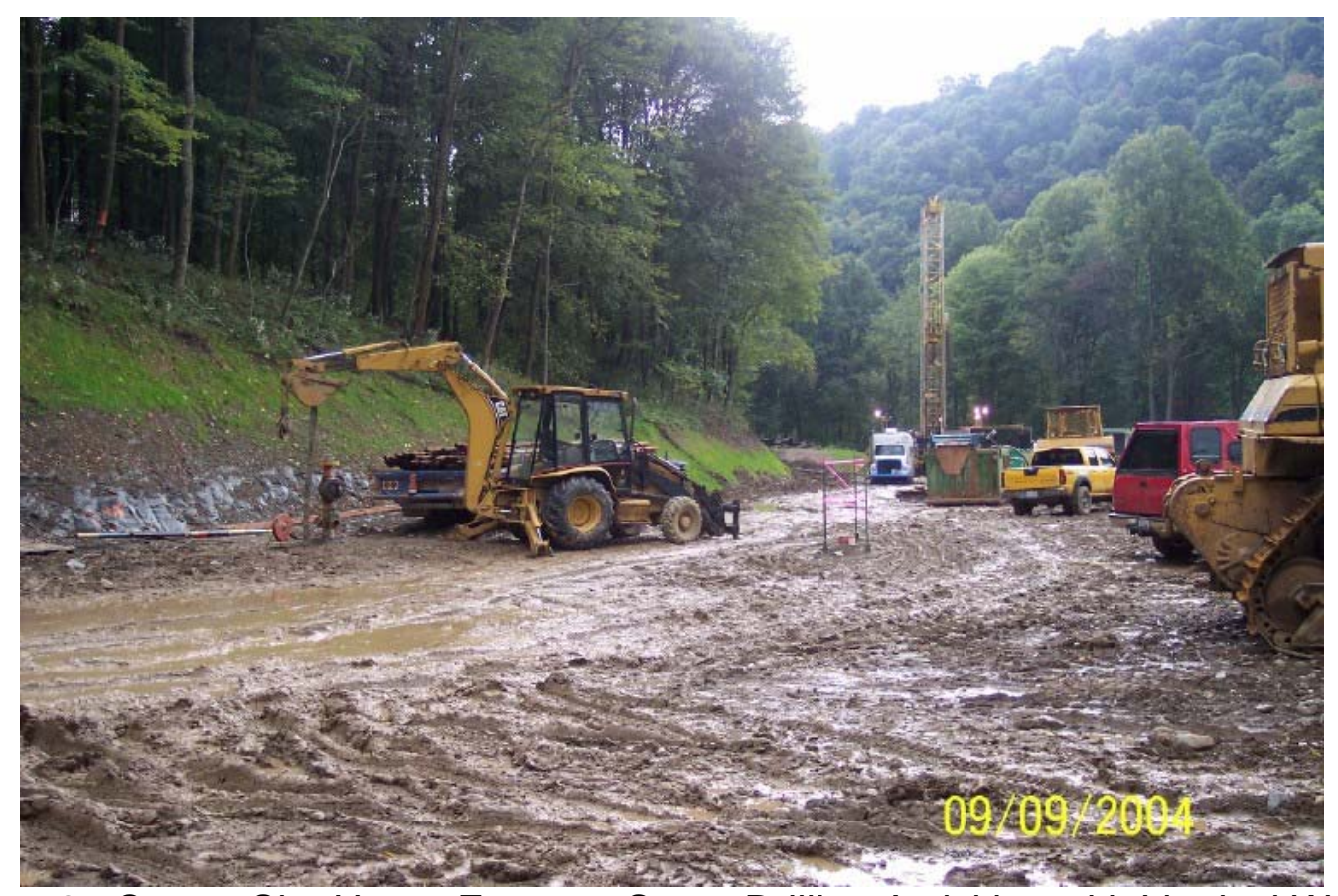

Figure 8: Center Site Upper Freeport Seam Drilling Activities with Vertical Well in Foreground and Access Well in Background - September 9, 2004

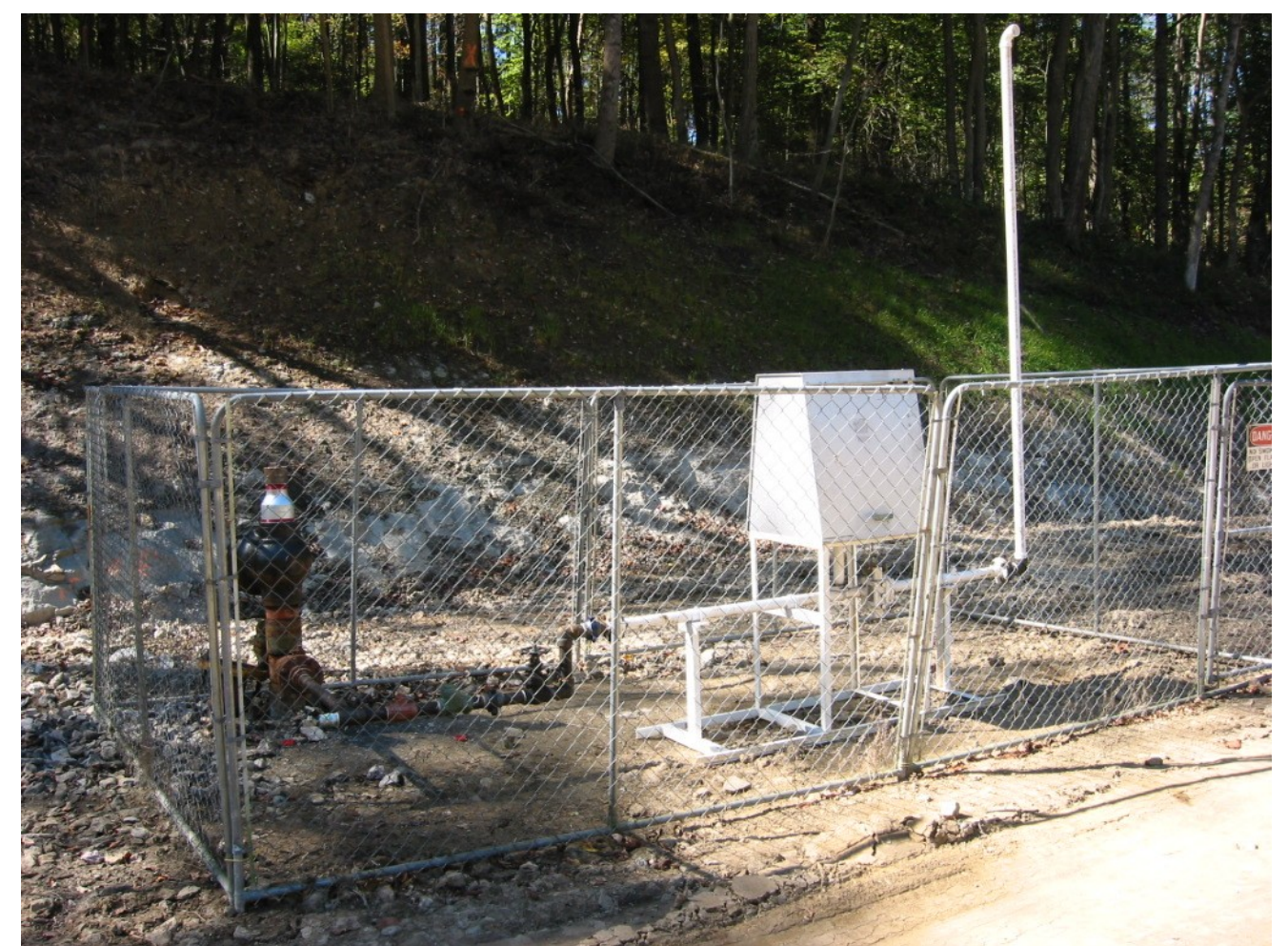

Figure 9: Center Site Upper Freeport Seam Southward Direction Venting System September 30, 2004 
Figure 10

Conceptual Perspective View of Project Wells

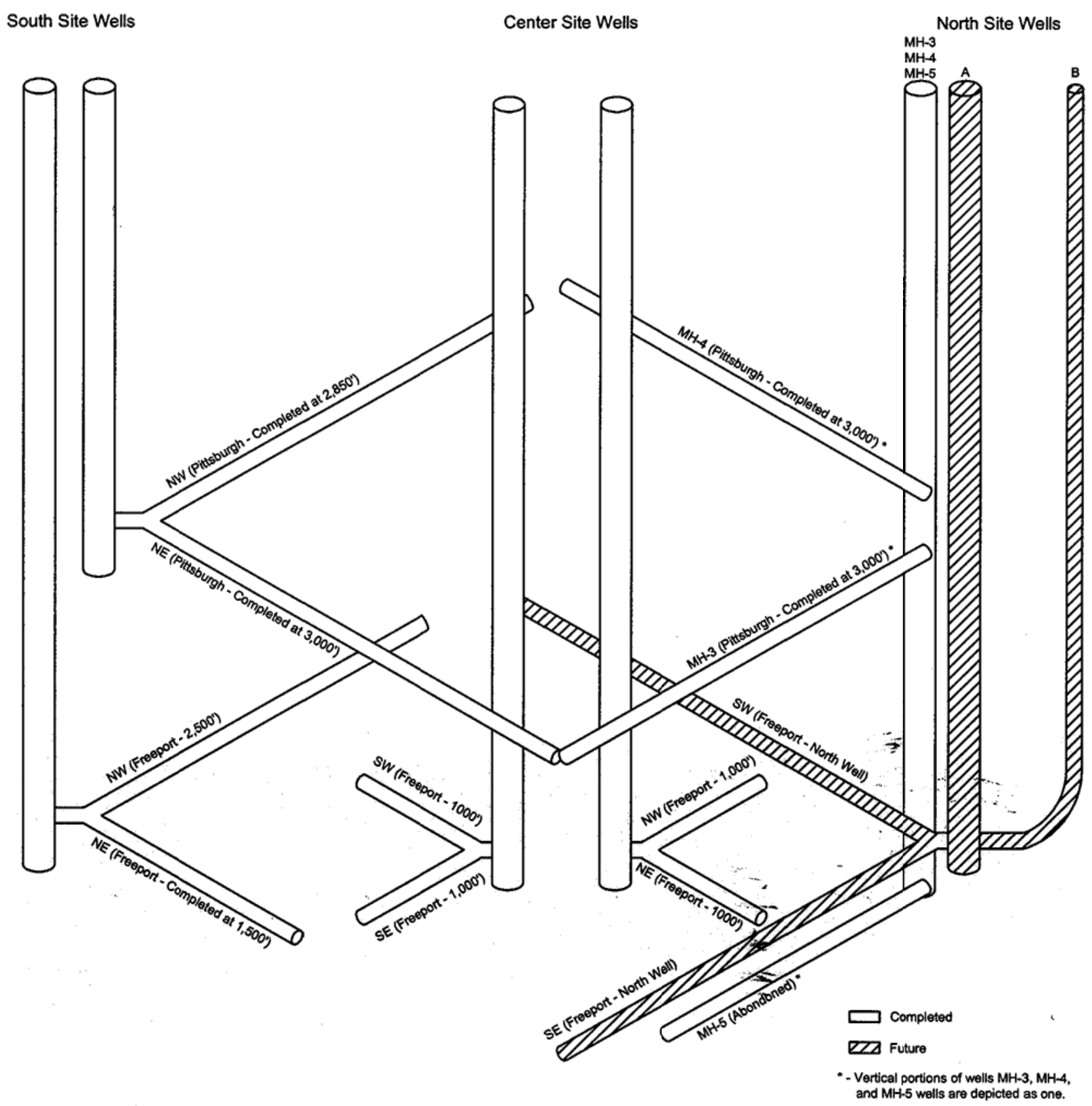


Figure 11

\section{Freeport Seam Drilling Plan}

North Site Well

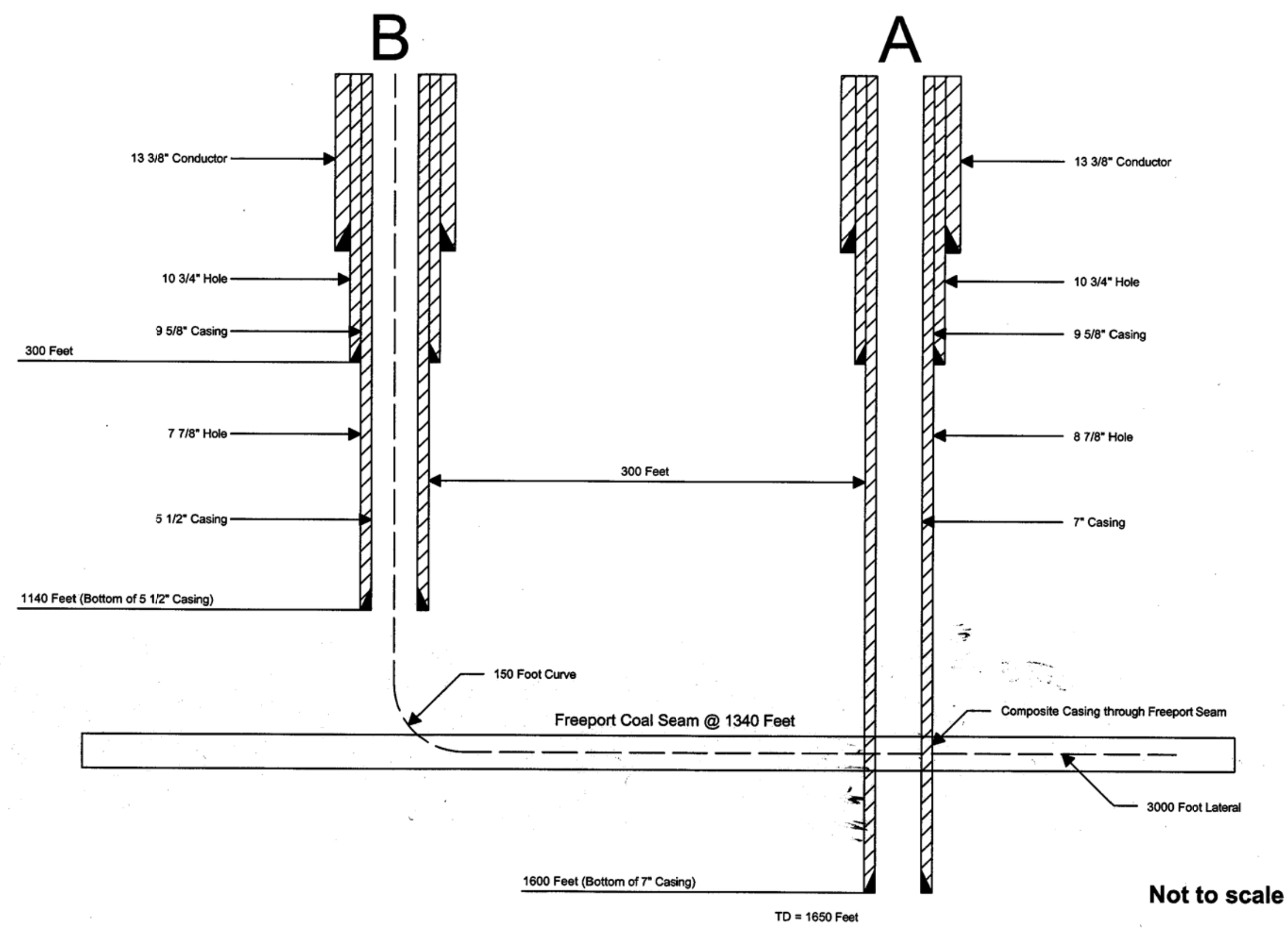

